\title{
The Life and Work of the anti-apartheid movement within the Church of Scotland from 1975 to 1985
}

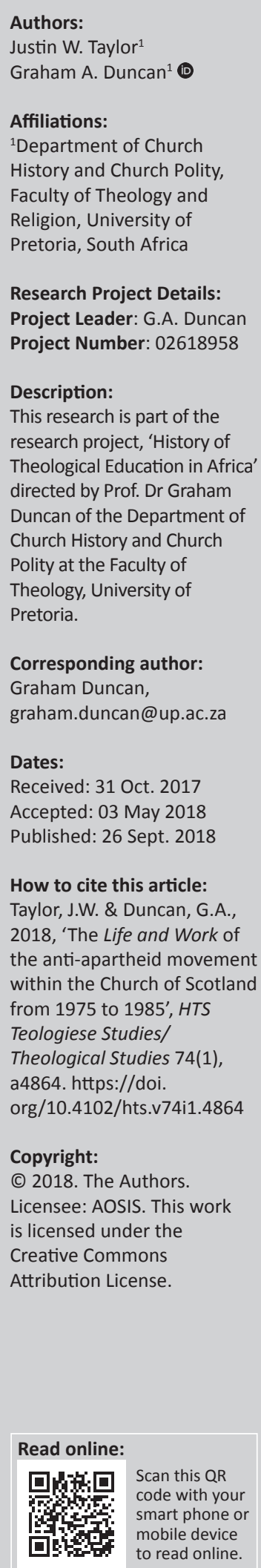

This article analyses the impact of the Church of Scotland (CoS) magazine Life and Work on the Dutch Reformed Church and other individuals and bodies during the period 1975-1985. It does this through investigating the editor's approach to South African affairs and the nature of contributions that he published. Significantly different views were expressed by those who had lengthy exposure to the South African context as missionaries of the CoS and 'tourists' (holiday makers, relatives of residents in South Africa and church visitors). As the period progressed, changing attitudes are discerned that came more and more into line with the anti-apartheid stance of the General Assembly expressed through its boards and committees.

\section{Introduction}

The Church of Scotland (CoS) produces a monthly magazine called Life and Work (L\&W). This magazine was established by Rev. Archibald Hamilton Charteris in 1879 under the title Scotland Life and Work:

In 1929 when the United Free Church of Scotland reunited with the Church of Scotland Life and Work was subtitled The Record of the Church of Scotland in recognition of the United Free Church publication, The Record, but this name was changed to Life and Work (L\&W) in 1996 when the magazine was relaunched in full colour. (Church of Scotland 2016)

There are very few extant resources relating to the magazine, let alone its reporting on the Dutch Reformed Church (DRC). This article will focus on the magazine's portrayal of the DRC in South Africa. It will show the changes in view of the editor at the time.

\section{South Africa in Life and Work before 1975}

Although reflections on South Africa before the aforementioned dates fall outside the scope of this article, it is important to note that South Africa did have a significant role in the magazine prior to the election of the National Party in 1948. Robert Kernohan (1979), the editor from 1972 to 1990 , stated the following:

At the time the Boer War seemed a great war, the first since Waterloo really to touch the life of the British people.

As things turned out it was soon to be overshadowed by a very different and much greater war. And as things turned out in South Africa itself, the people who appeared to have lost the war were soon well on their way to winning the peace and creating the new united South Africa after their own fashion....

It was also to bring problems of conscience and involvement for the churches: It was, after all, a Scots Presbyterian, Sir Henry Campbell-Bannerman, who coined the phrase about 'methods of barbarism' used against the Afrikaners whose descendants today are so frequently accused of methods of barbarism by ecumenical and other church groups. Yet it was Scots Presbyterians with such names as Murray and Robertson who maintained and renewed the Dutch Reformed Church after British occupation of the Cape. (pp. 55-56)

The above comments demonstrate the importance of the relationship between Scotland and South Africa. Firstly, Scotland had a history within the British Empire. The Scots fought as part of the British forces and were often important figures in the South African War (Second Anglo-Boer War), 1899-1902. Secondly, the CoS had a long-term relationship with the DRC. The CoS staffed a significant number of the DRC posts in South Africa during the 19th century because they were considered to be more theologically sound than their Dutch counterparts, and some of the most influential Dutch Reformed Ministers came from Scotland -including Andrew and John Murray, Alexander Smith, William Ritchie Thomson, John Bennie, Henry Sutherland, Colin Mackenzie Fraser, George Morgan, James Edgar, Robert Shand, John Cassie, Thomas Reid, Alexander Welsh and John Pears (Sass 1957:16). Thus, Scotland had a history with both the state and the church in South Africa. 
Yet, as stated above, until 1975 there were few sources available from which a policy could be discerned. Further, it was from this time that a clear response to apartheid could be discerned in correspondence and in articles published. In 1976, the Scottish anti-apartheid movement was established and was intensely proactive (SAAM 2018:1).

\section{Articles in Life and Work from 1975 to 1980}

The first article published in $L \mathcal{E} W$ was by the Rev. Graeme Brown, leader of the Iona Community in Scotland, who was the President of the Federal Theological Seminary at Alice for 3 years, from 1975 entitled 'Time against Race'. Although the author considered the rise of black consciousness as a positive force within South Africa, he also focused on the DRC.

In his depiction of various churches and their attitude to racial division he acknowledged that, although the 'Churches in South Africa inevitably [reflected] the trends in contemporary society and [could] be divided into "separatist" and "multi-racial" Churches', the DRC was struggling to accommodate people of all races. "The Dutch Reformed Church, for example, is organised on racial lines and is likened by some of its members to a "family" with a "mother" church (for whites) and "daughter" churches (for the African, Indian and Coloured peoples). Meeting of the races for worship does not generally take place in this "Family" (Brown 1975:22) in line with the decision of the DRC Synod decision of 1857:

\begin{abstract}
The Synod decided that it was permissible - whereas previously it was not - to hold separate services for whites and blacks. The decision was taken essentially on the basis of 'the weakness of some' (i.e. whites) - their weakness being a refusal to worship and be part of a racially integrated congregation. Whatever social pressures may have been at work here, or cultural justification given, the fact of the matter is that the DRC Synod took a decision which was in contradiction with Reformed teaching on the unity of the Church. Apartheid, at its worst, undermines the integrity of the Gospel and enforces division within the Church of Jesus Christ. (Van der Water 1991:94)
\end{abstract}

Dissent grew in the daughter churches as an Indian minister, Rev. E. Mannikam, discussed leaving the church because of the DRC's inability to sit around the same table during worship. One hundred ministers from the DRC in Africa stated 'we can no longer hold our peace against the ideology of separation of races on the basis of colour' (Brown 1975:22).

The DRC was compared to those seeking unity, for example with the Presbyterian Church of Southern Africa, the Bantu Presbyterian Church and the Tsonga Presbyterian Church. The problem was that 'union has been rejected by large numbers of black Christians on the grounds of the race attitudes of whites'. The hope was that a united black church could 'enter in dialogue with Christians on equal footing' (Brown 1975:22).

In Brown's eyes the 'Anglican, Methodist and Congregational Churches, which have a non-racial composition, seek to effect a fairer distribution of power among these members of all races'. He talked of how black people held top positions in these churches, which violated the 'almost sacrosanct convention in South Africa and that a black may not hold authority over white'.

Brown's understandings were correct in relationship to the DRC but failed in contrast to other churches. For instance, the churches of the Church Unity Commission - Anglican, Congregational, Methodist and Presbyterian - did not reflect 'a fairer distribution of power among these members of all races'. This began to change just after the 1974 DRC Synod, which published Ras, Volk en Nasie as its first movement away from apartheid. It is also interesting that both the Truth and Reconciliation Commission and the Kairos Document (Kairos Theologians 1985) challenged the English churches to more action. In his article Brown applauded what they were doing and how they were instigating change. The issue of communion and joint worship was also an issue even before the 1982 meeting of the World Alliance of Reformed Churches (WARC) when the membership of the DRC and the Nederduitse Hervormde Kerk was suspended. There was local and international awareness of this discrepancy in the DRC's theology prior to this.

In August 1976 L\&W featured a full-length main article by Rev. Dr Malcolm Mackay entitled 'Change - but How?'. This was the first edition following the June 1976 Soweto youth uprising; however, this article was written before the uprising. Dr Mackay was a former Australian Cabinet Minister, former secretary to the Australian Council of Churches and a visitor to the General Assembly of the CoS in 1976. Firstly, Mackay used black voices he encountered to establish his credibility (1976:10). The first, a black South African Member of Parliament, said 'I find it hard to believe there is a God when I think how the men who brought us our faith have treated us'. He then used the words of a black Dutch Reformed Minister, saying:

'What do you think it feels like to grow older and to know that when I am too tired to work anymore I will have no house, no property of my own - it is against the law for me to own land'. (p. 10)

Mackay (1976) commented:

$\ldots$ and then the picture became quite clear. Until very recently
the whites had deliberately kept the blacks unskilled, unable to
acquire property and indeed unable to compete with white
tradesmen or semiskilled labour. They were regarded unfit for
ordinary human intercourse but to be stabled and fed in minimal
conditions necessary for their optimum performance as servants.
Not quite slaves - but far from it either. (p. 10)

He argued that this was not the case in the so-called independent homelands where black people were trained; he produced no evidence to support this statement.

Secondly, Mackay spoke with a cabinet minister who believed change was happening but the timescale was the issue 
(1976:10-11). There is an interesting section where he wrote about the DRC and in particular Ras, Volk en Nasie. He said:

The greatest surprise, and it was a pleasant one, was the regard to the attitude of leading members of the Dutch Reformed Church. It was from this sector that some of the most intransigent attitudes in support of apartheid had once derived. Books written purporting to find Biblical justifications for the concept. Bitter reprisals were taken against those who dare to step outside the confines of the status quo. No doubt there are still plenty of Dominees who have sympathies with the ultraconservative, but I did not discover them.

On the contrary, talking with groups of theological students, younger ministers, professors of theology and retired ministers a wide cross-section - I found the universal recognition that change was overdue. Some men indeed indicated readiness to stand out against all attempts to intimidate or silence them. Yet, through it all, I had the impression that they felt there was more time available for change than I gathered when talking to black, coloured or Indian leaders.

One can only accept the integrity of these comments at face value in light of the circumstances of the time. Thirdly, he spoke with black men about 'facing the full discrimination of their hurts and injustices but with firm and certain convictions about the true scale of values' (Mackay 1976:11). In Mackay's understanding black people were not communist and inherently did not seek violence; they had a deep Christian conviction and were ready to suffer and compromise. Black people had every right in Mackay's eyes to harbour bitterness and hatred:

[I]n their situation I would not only be angry and determined to fight such obvious injustice, as they were, but I would also be bitter and full of resentment, which I have conquered.

Fourthly, he focused on the hurt and the pain that was present in both black people and Afrikaners. The question was raised by Mackay of 'whether this situation was not a result of colonialism and mistreatment of the British towards the Boers'.

Fifthly, he believed that time for change was short and white people had either to change or face violence (Mackay 1976:11). However, he believed South Africa provided hope for the world because it had the potential to change and it would all begin with repentance and apology. He said:

Nothing is so powerful as an idea when it's[sic] time has come. It is my conviction that the riches of character, of faith and of morality - which are more evident in South Africa today than any other nation I know on earth - will be the tinder which can be set afire with a new way of change. It is for this miracle of change in human hearts and minds that I as a Christian am called to work and pray ... the greatest power in the world is not an army or the atom. Mao is hopelessly wrong when he says that all power grows out of the barrel of a gun. There is a power which can melt the cold hearts of men, and it is offered to South Africa today. (p. 11)

This article is fascinating as it not only debunks the apartheid rhetoric that black people were communist but it also revealed them as peaceful and seeking a peaceful resolution.
The decision on whether violence was to be used was not in the hands of black people but rather in the hands of white people. White people were at fault and had the choice to move towards reconciliation. The problem was that it might be happening at too slow a pace.

Then the June 16 uprising in Soweto occurred. The uprising was covered within $\mathrm{L} \& W$ with reports of that day stating that violence was not again coming from black people but rather was from white people.

The November 1976 issue of L\&W was the precursor to the moderator's (Rev. Prof. T. F. Torrance) article about South Africa, which was to be published two months later following a brief visit to South Africa. The editor in the 'Newsdesk' (formally known as 'Church at Large') section of L\&W wrote a short piece entitled 'Risk of "Immense Eruption" in South Africa - Moderator'. In this section, Kernohan gave a summary of what the moderator had said since his return from a month-long trip to South Africa (1976:8). Torrance had asked the British Government and the World Council of Churches (WCC) to recognise the Transkei and Ciskei homelands despite opposition from churches in this regard, contrary to the policy of the Church of Scotland Overseas Council and the General Assembly.

Torrance's visit was not on the moderatorial tour agenda but happened as the result of his personal initiative following receipt of an invitation from the DRC. Torrance believed that 'there had not been sufficient theological criticism of the way apartheid and separate development had operated'.

Kernohan focused on three points from the moderator's visit:

Most black people are against violence. But many blacks want to create 'the kind of trouble which will force attention from the whites', many of whom do not know what black social conditions are like and have 'tunnel vision'.

There is a need for Church unity and combined effort in South Africa. The Moderator, who was guest of the Bantu Presbyterian Church, criticised 'some Scotsmen' in the mainly white Presbyterian Church of Southern Africa for concentrating on 'running their own congregations rather than the outreach of the Gospel and "going forward with others". He spoke of being appalled and ashamed'.

Black Christians 'put first things first in Christ' and even criticised missionaries who seemed 'more concerned with social issues'. Apartheid should be tackled in the light of the new freedom in Christ.

In January 1977, Torrance, moderator of the CoS's General Assembly, had an article regarding his visit to South Africa published in $L \mathcal{E} W$. The article was entitled 'The Moderator in South Africa', with the subheading 'The Rt. Rev. Professor Tom Torrance reported on his recent visit to the land where the wind of change is gathering force' (Torrance 1977:14-15). 
In his introduction he focused on his childhood growing up in a missionary family and his engagement with the Bantu Presbyterian Church. The Bantu Presbyterian Church excited Torrance, as they looked on missionaries with great favour. He (1977) said:

I was very excited by the way in which the Bantu Presbyterian Church in particular look back upon their origin. They look back upon the first missionaries, who brought them light in their heathen darkness, with the enormous reverence and thankfulness. The succeeding missionaries, too, were very highly revered and I must say that this whole attitude toward the Church of Scotland and others to help them was both humbling an exciting. (p. 14)

He pointed out that Bantu Presbyterian Church was the first missionary church to gain independence but they still organise themselves on the same Presbyterian principles as the CoS. One of the challenges faced by this church was that because of apartheid black people did not have the funds available to support both the church organisation and the local church. He acknowledged that apartheid had been a debilitating force in the prevention of black people attaining their true human identity as Christians by denying them the ability to fulfil the three self-principles of Venn and Anderson, to become selfsupporting, self-propagating and self-governing, prime features of the missionary enterprise for almost 100 years (Bosch 1991:331-332).

Then Torrance suggested that some European practices did not fit into the South African context. Presbyterianism and in particular running a presbytery meeting in the South African context did not work in the same way as in Scotland. This is because it was a foreign concept to them. He patronisingly believed the $\mathrm{CoS}$ should have allowed them to develop their own way and traditions, even if that looked Episcopal in structure. However, Torrance did not realise that Presbyterian polity had been in effect since the Presbytery of Kaffraria was established on 01 January 1824 (Cory MS7514) and had been integrated successfully into the life of the Scottish mission.

He focused on the positives that European culture brought to the church such as the reformed liturgical tradition. He continued by saying that the Bantu Presbyterian Church was no longer her daughter church but a sister church where black consciousness was not a problem:

In talking to the Federal Seminary outside Pietermaritzburg I pointed out that the consciousness theology that developed in the 19th century looks straight into the 'German Christians' and to the Nazi movement in Germany; and the German culture, the German blood-and-soil-consciousness theology was an extremely damaging thing to the Christian Church.

There can be no black theology any more than there can be a white theology. There are distinctive African ways of thinking and these have to be encouraged and these are basically what I have spoken of as relational and structural ways of thinking and these are precisely the ways in which in any case we have now learned to think in modern times. (Torrance 1977:14)

This kind of thinking denied the reality of the situation. There was a black theology in South Africa precisely because there was a white theology, however it might be designated.
Torrance continued by saying that the Bantu Presbyterian Church was paradoxical in nature. On one side they saw themselves as an independent church - Torrance questioned whether the CoS should have continued to send missionaries as it had done in the past - whilst they felt it needed the CoS and therefore wanted to create a joint church, the model in which he was brought up in China many years earlier. If this were the case, Torrance (1977) felt that CoS missionaries were:

not to go out to be pastors of others or the mission station but to work with them and other Presbyteries in order to help them develop an aggressive, in a proper sense, missionary outlook. (p. 14)

Here, his statements are in direct contradiction to the policy of the Church of Scotland Overseas Council, which had been promoting the concept of partnership in mission since 1965 (Duncan 2008:124-126). David Lyon (1998:5), former general secretary of the Overseas Council, stated that: '... partnership in mission between the Church of Scotland and Churches in former "mission fields", now increasingly a reality was bringing new and creative relationships'.

Torrance (1977) then turned to the greater social problem in South Africa. He felt that it could be summarised as 'developing polarisation of nationalism, black and white'. Afrikaners were narrow-minded, but this was because they had to work within government legislation, which they themselves created. He felt that Chief Buthelezi (the Zulu Chief Minister) was more balanced when it came seeing the racial problem from both sides:

... the white opposition in South Africa seems to me really to be empty of anything very positive or creative. I was deeply disappointed by their whole outlook. While they are desperately opposed to apartheid they really have nothing of significance that is genuinely creative or positive to offer for the future. (p. 15)

Torrance produced nothing to support his assertion that Afrikaners were 'desperately opposed to apartheid'. In the next section Torrance focused on helping the Transkei, as it had become an independent homeland in South Africa. He believed what the Transkei needed was Christian support, especially now that it had been recognised; they were seen as an independent state by the South African government but not recognised internationally.

Torrance (1977) then focused on why he felt they should be supported, because he believed the Transkei could become either secularist or Marxist. Britain also had a debt to pay to them because of colonialism:

I believe that we in Britain have a particular debt here because some of them are quite clearly embittered, with Britain in particular, because we were the people who first incorporated them into the Cape Colony; and it was the South Africans who finally - in their way - acceded to their request, made again and again, to become independent. If we still refuse to recognise them we are simply throwing them back into the arms of South Africa, and therefore are doing our best, even against our intentions, to make them a puppet Government of South Africa; the opposite must be the case. Now if our Government cannot do 
that it is all the more important the Christian Churches should maintain strong friendship and strong support for the people of the Transkei so that they may develop in the kind of way that we and they would like. (p. 15)

He was totally unable to critique the rationale behind the homelands system. He continued by saying that he felt that the churches in South Africa and Transkei should unite. Western churches needed to step back and stop imposing theological and polity paradigms onto the churches. Churches should use their influence to encourage unity within South Africa so that a united church could heal the apartheid wounds. He also validated the homeland project, which the British Council of Churches (BCC) and the WCC had condemned. Having said all this, the actual result of homeland policy in the Transkei was a split in the Methodist Church in 1983 resulting from a dispute with the state president, Kaiser Matanzima. The Federal Theological Seminary of Southern Africa was driven out of the Transkei as the result of a perceived threat arising out of a Hero's Day service in 1975 in which Fedsem students participated only 2 weeks after their arrival in Umtata (Denis \& Duncan 2011:118-123), and the Anglican church, which had a seminary (St Bede's) in Umtata, was also threatened with closure by Matanzima.

In his last section Torrance (1977) challenged the DRC:

I have proposed to the Dutch Reformed Church that they should call a conference of all the Churches to consider how best they might together promote the gospel of reconciliation and then how best they might together combat those policies which have pushed people away from Christ and damaged the gospel.

This will not perhaps take place as quickly as I had hoped but I believe that we can help them do that and we cannot help them to do that, if all we do is condemn the D.R.C. They have, after all, had a great missionary tradition; we must support them, and it is the kind or missiologists that I met in Durban, Westville, who are largely Dutch Reformed people, who can be our greatest support. Those who are the leaders of the mission Church, the 'sending Kirk', can be of the greatest support to such a venture; now if we can support them in every way I believe that here would be enormous change which would affect not only the church and the missionary situation but the whole socio-legal and sociopolitical situation. (p. 15)

A section of the whole article is included in this article because Torrance constantly contrasted the various aspects of the complex situation in South Africa. Torrance believed that his theological challenge alone could sway the DRC and in the General Assembly of 1982 he referred to a meeting he had with the DRC 'behind closed doors' to discuss these issues. A South African missionary, Graham Duncan, asked him on the floor of the Assembly why the doors had to be closed. This indicated a lack of transparency in the DRC approach to the apartheid issue. In this he was supported by another minister of the Reformed Presbyterian Church in Southern Africa (RPCSA; the name of the Bantu Presbyterian Church had been changed to the 'Reformed Presbyterian Church' in 1979) who was studying in Scotland, Rev. Charity Majiza.
This article contradicted that of Graeme Brown. Torrance had spent a month in South Africa, where Brown had served for 3 years. Brown felt that black consciousness was a good thing where Torrance equated it to Nazi Germany. Brown saw the opposition as creative whilst Torrance saw it as destructive and with nothing to offer.

Torrance only made one reference to government in the whole article. Why was he silent about the political situation, especially when the Soweto massacre of schoolchildren had occurred just prior to his visit in 1976? He continued by saying that all international churches should support the unification of the churches in South Africa. It is interesting to note his contradictory support for the separatist political dispensation of the homelands policy whilst, at the same time, he supported unity in the ecclesiastical domain. He also then admitted that he felt that the churches should support the DRC 'in all ways'. This is a noteworthy comment as a few years later in 1982 the CoS went on to change this position at the WARC. The above understanding seems to be slanted towards a noncritical response to the South African situation. Is this because Torrance did not want to damage possible talks where he had offered to be the mediator - or is it because he only saw what the government wanted him to see, or was it because he did not fully grasp the situation?

Torrance's position was paradoxical. He was a highly respected theologian who had had a distinguished ministry both in the parish and in the academy. He came from a missionary dynasty that had historic ties with China and medical mission in Israel. However, as moderator of the General Assembly he was not a spokesperson for the CoS. That role was fulfilled by the church's boards and committees. He was only able to speak in his private capacity and the paradox is that many assumed he was speaking for the church during his period as moderator.

In the same edition of L\&W on page 34 in a small section entitled 'News from All Quarters', the following two small articles appeared:

Church and Nation convenor the Rev. A. Arnot Fleming sent a telegram to the South African Prime Minister, Mr John Vorster, expressing 'dismay' at the arrest of members of the staff of the South African Council of Churches and the Christian Institute of Southern Africa. It urged their release of 'at least' that charges be made public. Another telegram to the Rev. Beyers Naudé of the Christian Institute expressed sympathy and 'admiration for the courageous stand'.

The British Council of Churches has passed a resolution supporting the Government's non-recognition of the Transkei. (Unknown Author 1977:34)

These contradict the moderator's article. However, they appeared at the back of $L \mathcal{E} W$. Was this the result of an editorial decision by Kernohan, who agreed with Torrance but wanted to seem impartial? 


\section{Articles in Life and Work from 1980 to 1985}

The 1980s saw many changes in South Africa and internationally that indicated that the anti-apartheid movement was gaining in strength. Both the Belhar Confession (1982) (Kinghorn 1997:153) and the Kairos Document (Kairos Theologians 1986) were written during this period. The DRC and the Hervormde Kerk were also suspended from the WARC (1982) (Fortein 2013:311-312). The much-criticised new constitution with its tricameral parliament was introduced in 1983 (Fortein 2013:312), and in response the United Democratic Front was established (Fortein 2013:312). Desmond Tutu won the Nobel Peace Prize (1984) and became archbishop of Cape Town (1986). There was a major uprising in the Vaal (1988) following the banning of 17 organisations. Then there was a South African Council of Churches (SACC) sponsored march to present a petition to parliament, the inauguration of the 'Standing for the Truth' campaign, the bombing of SACC's Khotso House and the 1987 SACC national conference, which led to an apology from the DRC for its role in apartheid. The same conference initiated discussions that led to the establishment of the Truth and Reconciliation Commission (Allen 2006:342-347). All of these, in one way or another, put pressure for change on the government. P.W. Botha had come to power in 1978 (Beinart 1994:165), and a state of emergency was declared (1985) (Allen 2006:2-7).

In July 1980 a full-page article was placed in $L \mathcal{E} W$ titled 'Change and Conscience in South Africa Today'. The article by Peter Hannon was the first article to have a photo of a South African leader, P.W. Botha, in it. Although it was not about the DRC in particular, it showed a change in social thinking. Hannon was of the view that Botha was the hope for change in South Africa, as the mediator between 'black nationalism and Afrikaner nationalism' (Hannon 1980:16). It mentioned that Botha's government passed the law allowing for black trade unions and 'ha[d] made moves towards equal pay and job opportunities' (Hannon 1980:16).

According to Hannon, Botha believed apartheid was dead and therefore he was trying to chart a way forward to ending it. An opposition Afrikaner right-wing group was formed, but on the whole Botha had the backing of his cabinet. The hardship for Botha would be getting the black majority on his side whilst the National Party united. However, in the black community, the perception of Botha was split between those who thought he was a 'ruthless terrorist ready to sacrifice innocent lives' versus 'a martyr for the liberation struggle' (Hannon 1980:16). Those in the homelands were calling for open-ended negotiations.

Hannon (1980) quoted an unnamed Afrikaans professor, who said:

For generations our survival as Afrikaners has depended on our determination to go it alone, regardless of anyone else. It was only this spirit in our apartheid policy when we came to power.
Now suddenly we realise survival depends on consultation, and we don't know how to consult. (p. 16)

He continued by offering three points on how the CoS might be able to help the Afrikaners through the consultation process. Firstly, 'accept that much of what happens here is our responsibility'. Secondly, 'Southern Africans are not some peculiar breed with particular inclinations towards injustice'. Thirdly, 'can we search for how to work together with those forces within Afrikanerdom who struggle courageously for change?' (Hannon 1980:16).

This article indicated a real belief that South Africa was on the brink of change. The article was not focused on black consciousness but rather focused on the change in white thinking. White people had a prime minister who had decent people in his ranks, yet he also had the backing of his cabinet. He had plenty of experience working with various groups and put in place changes in policy that would positively affect black people. Hannon viewed the role of the CoS as one of mediator and friend offering support as South Africa undertook this journey.

In September the same year a letter was published by Rev. John Duncan. Duncan (1980) quoted an Anglican bishop who had recently come back from South Africa as saying:

The Church is usually expected to perform the task of reconciliation, but sadly in South Africa it has got itself into a position where it was unable to do this. (p. 6)

He was of the belief that reconciliation could only be achieved by reconciling oneself to Christ and then to others. He considered that reconciliation must be non-violent. He offered four things that people could do about the South African situation:

(1) We can accept and practice the Gospel of Reconciliation through the life of Christ ourselves. (2) We can pray regularly in private and in church for reconciliation and spiritual renewal amongst all races in South Africa. (3) We can encourage and support all those blacks and whites who are bringing people together through worship and witness, and through cultural, social and sporting activities. (4) We can recognise and welcome change and progress when it comes. (Duncan 1980:6)

Duncan's view is interesting because he felt that the church in South Africa was not a credible witness and had failed the people. He then spoke of personal piety rather than any understanding regarding the atrocities in South Africa. The Afrikaners were all pietists influenced by Andrew Murray yet they instituted apartheid!

Although the next article in the November 1981 issue of LEW was not written about South Africa but about racism, it shows that this was a prevalent issue in the UK at this time, especially because of the 1981 race riots in the UK and the situation in South Africa. The article entitled 'Racism - A Problem or an Opportunity' was written by the Very Rev. Dr W. B. Johnston, who was the previous year's moderator of the General Assembly and previous convenor of the Church and Nation Committee. At the time of writing this article, he was chairman of the BCC. 
Johnston asked why racism was present in people's views of the UK and why it was present in society. For him the answer was threefold. Firstly, '[i]t was a hangover of old imperialist and colonial ways' (Johnston 1981:18). In this section he explained how racism did not exist outside of modern Europe. It was a by-product of colonial expansion. Secondly:

racism is sometimes seen as the retention of safeguarding of privileges which are threatened. This view is focused in particular on two areas - those of immigration and of urban deprivation. (p. 18)

In the former case this is laws that protect national identity that is, who is a citizen and who is not - and in the latter case that people of colour do not share in the basic services enjoyed by white people. Thirdly:

the most subtle but perhaps the most powerfully emotive fact of all is that we tend to see racism as a problem created for $u s$, instead of realising that it is at least a problem created by us. We think of our white society in this country as being uncomplicated and homogeneous until 'they' came and created the problem of race. (p. 18)

Johnston (1981) said the church's role:

... lies with the understanding of the Church as the alternative society. In the church we are committed to the creation of a pluralistic society - the whole of the New Testament emphasises the nature of the Church as comprehending men, women and children of all races and conditions and classes. As our society (both in Europe and throughout the world) becomes more fragmented and polarised and as we therefore move steadily deeper into crisis, so the need for the Church to be and to show itself to be the alternative society becomes ever more urgent. (p. 19)

Johnston felt that racism was a problem of all people in the UK, whether it be local or international. The church had an opportunity now to make a positive impact. Bodies like the WCC and the BCC had been misunderstood, as they were not sowing division, and therefore people should rally behind them.

In July 1982 - before the WARC meeting in Ottawa in which the membership of two DRC churches was suspended - an article entitled 'The Gospel Compels Us to Keep Contact' was published in LEW. Written by Rev. Duncan S. Watson - a visiting fellow from Princeton Theological Seminary, a Baptist minister and a senior lecturer at the University of Durban-Westville in Natal - it focused on the church's relationship with DRC. This article was written before the WARC meeting in which the DRC was suspended. Watson wrote the article because he had heard rumours that various reformed churches wished to excommunicate the DRC, which he felt was the wrong approach. He felt that this was contrary to Gospel teaching in special relation to the centrality of grace. He then reminded readers that this idea of excommunication was a Roman Catholic concept and went against Reformed principles. This is not true, for Calvin and other reformers used excommunication in the form of deprivation of the saving graces of the Church, that is, the sacraments.
Watson (1982) wrote:

We are not God. In the DRC Jesus Christ is proclaimed and the sacraments are celebrated, imperfectly to be sure they are there at the centre. (It is a worthy of note that the Black [African] Reformed Church associated with the DRC is a large and fast growing church, especially when compared with other mainline Churches. How can this be if the DRC is utterly defective in regard to the Gospel?) The DRC has strengths from which we can learn. (p. 26)

According to Watson the Bible is full of examples where God did not give up on his people. This is found in God's relationship with Israel and how Paul does not reject association with the synagogue. He believed that by ostracising the DRC we failed to recognise them as Christian. The Gospel for him was about reconciliation through grace and not through culture or race. He failed utterly to understand and interrogate the Reformation context, which required strong measures to succeed against the monolithic Roman Catholic Church.

The second point he raised was that there were those in the DRC who were seeking change. He felt that they should not have been cut off. He said that the DRC were poor in two senses:

The first is that amongst the people of the world Afrikaners are spoken of as pariahs. If they are seen to be such, are they then not, as outcasts, of special concern to the Christian world community, who need to stand alongside them? That may be asking and risking much but it is something the contemporary and greatly emphasised concern for the poor surely must imply (as Jacques Ellul pointed out in his book, 'Violence,' in reference to 'unpopular' poor).

Naturally, one may object that many Afrikaners are in disfavour for very good moral reasons in that they have treated others as beyond the pale. That is true, but it reminds us of the more basic understanding of the word 'poor'. The poor as sinners. 'While we were yet sinners Christ died for us.' Christians are to be ambassadors of that Christ who reconciled the world to God not counting sin against it. All of us Christians still stand with the world in this respect. Of course, as Reinhold Niebuhr pointed out, there are bigger and lesser sins and many aspects of the apartheid policies which the DRC implicitly supports are major in their sinfulness. That, I think, Christians must quite clearly say to the DRC brothers and sisters - but as brothers and sisters, not as enemies for if as enemies then we have cast the first stone and declared ourselves without sin. (Watson 1982:26-27)

He then continued by saying that expelling the DRC would give weight to the thought that the 'Church is going Marxist' and that their aim was to divide Afrikaners until they existed no more.

He therefore believed that it was against the biblical and moral obligation that the church was required to uphold. Again he failed to recognise and ignored the reality that the DRC was a para-political organisation. It is noteworthy that he eschewed mention of Paul's 'principalities and powers' could this have been selective amnesia? It is interesting that Watson did not explain why the WARC wanted to expel the DRC. Who were these people and what exactly was the 
theological division? He also failed to take account of the second exodus narrative where God sent the Israelites into exile. This matter was of interest, because the DRC must have known the agenda of the WARC before they went to the conference.

In the same article was a small sidebar that contained the following snippet entitled 'Disagreement on South Africa':

During the Assembly discussion of the Overseas Council report evidence of considerable disagreement emerged between some of those in the Council and the Very Rev. Professor T. F. Torrance. Professor Torrance suggested that the council perhaps did not have the 'objectivity' to handle dialogue with people in the white Dutch Reformed Church in South Africa who were opposed to apartheid. He said there was likely to be a 'volcanic eruption' in the next Synod of the Church and wanted an assurance that the Overseas Council would do nothing to discourage or hinder those who took this line.

The Council convenor, the Rev. Colin Martin, said 'it would not be our wish to obstruct this' but that the Council would be guided by its relationship with its partner Church in South Africa, the Reformed Presbyterian Church (Formerly the Bantu Presbyterian Church). The Rev. Ian Moir of the Overseas Council staff said there was no opposition to dialogue or principle to discussion with the white Dutch Reformed Church but refereed to 'advice' from the Association of Black Reformed Christians that this was not the time for dialogue. He said that there had been a volcanic eruption already in the daughter Churches of the DRC. They had joined the SACC. (Unknown Author 1981:26)

The preceding article represented the differing viewpoints of what and how to handle South Africa. The discussion happened at the General Assembly and this showed that the church's Overseas Council had moved to support those who were being oppressed. This was the first time that the church's position from an assembly had been featured as part of a full article. Torrance had been to South Africa on the invitation of the DRC. This might have impacted his response. He was not part of the Overseas Council at the time.

In October 1982, an article appeared in $L \mathcal{E} W$ about the WARC meeting in Ottawa. The article was titled 'Apartheid's Shadow over Reformed Alliance' and was written by Bruce Cannon (communications director of the CoS). The opening line of the article read, 'Ottawa 1982 will probably be remembered as the place and year when reformed churches finally lost patience with some of the white members of the family in South Africa. Two Churches were voted "into suspension"' (Cannon 1982:10). Cannon talked about how the opening ceremony was a shock. Eleven Ministers from a delegation of South Africans - he does show that two of them were white - refused to take sacraments as a sign of protest against the apartheid regime. Cannon says that the protest made many delegates 'unhappy' because it showed that the issue was still a problem.

He then went on to talk about how the meeting unfolded and said that three subdivisions were set aside for the apartheid issue and an unscheduled public hearing was held where all parties could state their views on the matter. The three sub- division groups came together and called for the suspension of the DRCs for their 'moral and theological justification' of apartheid (Cannon 1982:10). The WARC believed that apartheid now risked tainting the Reformed tradition. 'The group further described apartheid as a sin, a travesty of the Gospel and a theological heresy' (Cannon 1982:10). Cannon (1982:10) suggested that the debate about suspension was both calm and balanced. The churches were both suspended until they could show that they had changed. This meant ' $[n]$ o exclusion of blacks from services, support for those who suffered under apartheid, and unequivocal resolutions ... committing themselves to dismantling apartheid in both the Church and politics'. The WARC council elected Rev. Allen Boesak as its president. In this section Cannon explained who Boesak was to the readers: his church affiliation, black theological stance and his role in the anti-apartheid struggle. Cannon then went on to discuss other matters that were raised in the meeting.

This was the first time that Allan Boesak was introduced into the magazine in any shape or form. Although painted as a proponent of black theology, Boesak was portrayed in a positive light. He was someone who had credentials and had the trust of those around him.

Cannon depicted a very positive outlook on how the WARC meeting in Ottawa was conducted. He at no point suggested that people felt bullied but rather expressed that the decision was carefully and meticulously arrived at by mutual consultation. Even the photograph that was chosen for the article does not show Boesak in a negative light but rather as a thinker. This kind of article represented a move away from the previous articles, where the focus was predominantly on the DRC and the CoS's relationship with it. This article now framed black theology and the Black Consciousness movement in a very positive light. In so doing the DRC were moved out of the limelight and seen as those who were wrong and had to be held accountable. The August issue in 1983 featured the following prayer:

Father of us all, before we can pray for South Africa we must ask forgiveness for ourselves. We have our own Apartheid of race, class, and creed. As a developed Country we have our privileges at the expense of the weak. Our hands are not clean. Forgive us. Human dignity and unity are Your will. But we see a people divided and we see people oppressed.

We pray for the Government of South Africa under pressure, from the world, and within its own borders. May its leaders see Your way for the future.

We pray for white South Africans, afraid of black political power; for black South Africans, diminished by the laws of their country; for Coloured and Indian communities, with minor privileges, yet restricted. May all be freed from their bondage.

We remember the sufferings of South Africa, people transported to 'homelands', those in prison for conscience sake, white and black rejected in their communities because they speak peace. You are their strength.

We pray for companies with South African interests, for visiting sportsmen, for those of us with friends and relatives in South Africa. Help us all to be wise and just in the stand we take. 
We share the travail of the Church in South Africa; the Dutch Reformed Churches, believing apartheid is Your way; the Reformed Presbyterian Church, denied its fullness as part of Christ's Church because of race; all Christian bodies torn between acceptance and resistance. May the Church be a channel of Your truth, and Your healing power.

We thank You for the faithful witness of South Africans both black and white who still trust in You and have hope, and who are Your light in the darkness. Bless Your people of South Africa. (Unknown Author 1983:19)

It is interesting to note the change in boycotts to reflect sportsmen, families and companies. This issue had not connected on the periphery but had real-life consequences for people. Questions were asked: When you boycott South African produce are you not in turn boycotting your family in South Africa? If one had to boycott South Africa, could you lose your job because your company had so heavily invested in it? Apartheid therefore had international consequences. How does a church boycott in a way that does not boycott the family relationships and jobs of its own parishioners?

In December 1983, the editor of $L \mathcal{E} W$ published an editorial comment about South Africa entitled 'Change in South Africa?' In the article he talked about the change in current South Africa. Kernohan believed things were changing for the better. He only had to look at the calibre of leaders, 'including Christians', coming from South Africa. The South African government was beginning to see the human dignity of all South Africans and was changing laws, and some of the DRC were showing 'a real crisis of conscience' (Kernohan 1983c:5). He did wonder how change would come to South Africa. Would the majority seek violence as much as those who had oppressed them? He believed that this seemed a likelihood unless God could do something.

In March 1984, the editor of $L \mathcal{E} W$ wrote a comment about a visit Allan Boesak had made to Edinburgh earlier that year. Kernohan reported that Boesak believed that not nearly enough pressure had been put on South Africa. Boesak then asked the church for 'consistent, sustained action of the Church on behalf of victims of oppression ... insisting there is no middle ground left' (Kernohan 1984a:11). Boesak also focused on stronger economic pressure and the failure of the DRC. He then went on to attack the homeland leaders. For him, the homeland projects were also a key to dismantling apartheid. If they failed, the state could not hold together their separation policy. He also defended the SACC not as a radical organisation, but one hopeful for peaceful change. What is interesting to note in this article is Kernohan's more positive approach, and the WCC and the BCC's view that the SACC were agents of Marxism to be avoided. None of that rhetoric is present in this article.

From April to June 1984, Kernohan published four articles in $L \mathcal{E} W$. These were the longest articles about South Africa ever published. In April, he published 'From a South African Diary', where he focused on some of his observations of places he had visited. He first spoke about being in
Stellenbosch, where he went into the heart of 'Afrikaans culture' and 'Dutch Reformed theology' (Kernohan 1984b:22). He was encouraged by the DRC Synod's call for the removal of racial barriers in churches, mixed marriages and the idea that apartheid could be justified by scripture. It was here that Kernohan (1984b) reflected the Afrikaner people:

All this must be part of an analysis of the new South African situation: indeed, it is at the heart of it. At this stage there is only room for a paradox. This is it that the Afrikaner people, often so rigid and forbidding in their collective stance, produce such warm hearts, kind welcomes, and fine minds as Stellenbosch can offer? Professor Willie Jonker gave me a chance to realise that what is happening in the DRC comes from the heart and conscience of the Church, not from any calculations of diplomacy or expediency. (p. 21)

This was also contrasted by his visit to Pretoria, where he met Rev. Nico Smith, who had been changing the face of white Afrikanerdom as he was living in Mamelodi Township and ministering in a black congregation. Kernohan was taken aback by Smith's approach.

In the May issue of $L \mathcal{E} W$, Kernohan published his second article on South Africa; however, he does not mention the DRC. In the June issue of $L \mathcal{E} W$ he looked at how Afrikaner nationalism was the barrier to effective change in South Africa.

Kernohan published his third and last article in the July 1984 issue of LEW. He believed South Africa was changing. Afrikaner nationalism was no longer working and apartheid as it was then understood was changing. For Kernohan there was grounds for hope. He believed that economic growth would not ease the tension so he encouraged the readers to find things that organisations were doing to help economic change in South Africa. He believed that even though social changes were taking place and black people were becoming more affluent the reality was that it was not about wealth. The church was playing an important part in this development. He believed that the South African churches were dominated by an agenda, but he believed that it had an important place in South Africa. Churches in South Africa still needed to bring people around the table for discussion, and they had enough influence to do so.

For Kernohan there were two signs of hope for South Africa. Firstly, 'the continued role of Christians in Black leadership, even if the style and idiom had changed considerably since Albert Luthuli' (Kernohan 1984b:23). It was here that he recognised Desmond Tutu, Allan Boesak and Alan Hendrickse (a leader in the tricameral parliament) as inspirations in the community. Secondly:

in the white Dutch Reformed Churches ... these Afrikaansspeaking Presbyterians (as they are in theology and church order) were no more of one of mind than Scots Presbyterians, or for that matter the South African English-speaking Presbyterians with their direct descent from Scots colonial congregations. (p. 23)

The DRC was splitting as ministers were changing their views and were standing up against apartheid. There were 
two divisions that occurred as the result of Afrikaners from the far right politically leaving the Nationalist Party of government: the Herstigte Nasionale Party was formed in 1967 and the Conservative Party in 1982.

He then spoke about the failed attempts to unite the Presbyterian Church of Southern Africa and the Bantu Presbyterian Church, not to mention the Tsonga Presbyterian Church (Swiss Mission) and the Presbyterian Church of Africa (formerly Scottish Mission); he felt this demonstrated how racism had torn them apart where the church's theology should have drawn them together. He felt that there were some dilemmas that South Africa needed to overcome. Firstly, had the Afrikaans community moved too late? Secondly, could the future economy distribute wealth? Thirdly, could nationalism and culturalism coexist? Fourthly, could a new form of governance emerge that would not have the same oppressive nature as the previous government? $\mathrm{He}$ believed that only God could work out these dilemmas.

The last major article about South Africa from 1980 to 1985 in LEW was published in August in 1985, entitled 'Cracks in the Dividing Wall of Apartheid'. The article was written by Rev. Blessing Finca, who was a senior black minister of the CoS's partner church, the RPCSA. This was the first article written by a South African in LEW. Finca said that in Scotland people were not only interested in events in South Africa but also in how to interpret them. For him the main concern was to stay faithful to the gospel and not abandon it in the pursuit of freedom. The prevailing theology during colonial times was the inferiority of black people and this had continued in apartheid. He then pointed to Steve Biko and Nelson Mandela as people who had held the light for all to see. They had said that it was the dismantling of apartheid that they wanted. White people in South Africa had insulted black people by controlling them through laws and decisions made without consultation with the black people affected by the same laws (Finca 1985:14).

White South Africans believed black people were stupid. Yet their government failed to see how perceptive many black people are. The government also tried to use wealth as a weapon to diminish black political ambition and those who did not comply with legislation directed against them were met with violence. He then turned his attention to the church in South Africa, which he believed was in conflict. Neither English- nor Afrikaans-speaking churches challenged apartheid because they benefitted from it. The SACC helped black churches to find their voice. All the Christian liberation organisations that were formed arose from the need to dismantle apartheid. Thus, the church among black South Africans was both a social and political help (Finca 1985:1415). Even though the government had called for talks, it needed to speak to leaders who opposed apartheid. It had to speak to those in prison or who were in exile. Finca believed that real change was possible but that the system then in place would lead to more bloodshed. Finca challenged the Scots to adopt a strong boycott. This was taken up by the Women's Guild with considerable earnestness, energy and success.

\section{Conclusion}

The CoS policy regarding South Africa was clear. However, the membership of the same church was ambivalent. This was possibly the result of ignorance or not wanting to believe the truth of the situation. Support for apartheid was notable among CoS tourists, family members and those who visited South Africa for limited periods and never entered townships. It was missionaries like Brown, Moir and the Duncans (who were only mentioned indirectly) who had long-term exposure to the realities of the context who were more articulate exponents of the reality of apartheid. For instance, Brown was ahead of his time, as it was only from 1982 that his understandings were to be reflected in L\&W. The majority of the articles prior to that supported the DRC.

What was presented as attempts at mediation, negotiation and talks (formal and discreet) were in reality delaying and avoidance tactics and ultimately supportive of apartheid. We must always remember that silence and inaction in the face of evil mean collusion with the 'principalities and powers'.

\section{Acknowledgements Competing interests}

The authors declare that they have no financial or personal relationships which may have inappropriately influenced them in writing this article.

\section{Authors' contributions}

J.T. researched the aforementioned topic by going to the archives of L\&W at the Church of Scotland's head office in 121 George Street Edinburgh. Both G.A.D. and J.T. worked on the article to produce its finished form.

\section{References}

Allen, J., 2006, Rabble rouser for peace: The authorised biography of Desmond Tutu, Random, Johannesburg.

Beinart, W., 1994, Twentieth century South Africa, OUP, Oxford.

Bosch, D.J., 1991, Transforming mission: Paradigm shifts in theology of mission, Orbis, Maryknoll.

Brown, G., 1975, 'Time against race', Life and Work, March, p. 22.

Cannon, B., 1982, 'Apartheid's Shadow over Reforemed Alliance', Life and Work, October, pp. 10-11.

Church of Scotland, 2016, Life and work history, viewed 04 May 2016, from http:// www.churchofscotland.org.uk/news_and_events/life_and_work/life_and_work_ history.

Denis, P. \& Duncan, G.A., 2011, The native school that caused All the trouble. A history of the Federal Theological Seminary of Southern Africa, Cluster Publications, Pietermaritzburg.

Duncan, G.A., 2008, Partnership in mission: A critical historical evaluation of the relationship between 'older' and 'younger' churches with special reference to the Church of Scotland, VDM Verlag Dr Mulleer, Saarbrücken.

Duncan, J., 1980, 'First post', Life and Work, September, p. 6.

Finca, B., 1985, 'Cracks in the dividing wall of apartheid', Life and Work, August, pp. 14-15.

Fortein, E., 2013, 'Alan Boesak and the Dutch Reformed Mission Church between 1976 and 1990', in M.A. Plaatjies-van Huffel \& R. Vosloo (eds.), Reformed churches in South Africa and the struggle for justice: Remebering 1960-1990, pp. 303-315, SUN Press, Stellenbosch.

Hannon, P., 1980, 'Change and conscience in South Africa today', Life and Work, July, pp. $16,36$.

Johnston, W.B., 1981, 'Racism - A problem or an opportunity', Life and Work, November, pp. 18-19. 
Kairos Theologians, 1985, The Kairos document: Challenge to the church: A theological comment on the political crisis in South Africa (First), Skotaville Publishers, Soweto.

Kernohan, R.D., 1976, 'Risk of "Immense eruption" in South Africa - Moderator', Life and Work, November, p. 8.

Kernohan, R.D., 1979, Scotland's life and work, St. Andrews Press, Edinburgh.

Kernohan, R.D., 1983, 'Change in South Africa?', Life and Work, December, p. 5.

Kernohan, R.D., 1984a, 'Not nearly enough pressure on South Africa', Life and Work, March, p. 11.

Kernohan, R.D., 1984b, 'From a South African diary', Life and Work, April, pp. 21-23

Kernohan, R.D., 1984c, 'What evidence for things hoped for?', Life and Work, July, pp. 22-23.

Kinghorn, J., 1997, 'Modernisation and apartheid: The Afrikaner Churches', in R. Davemport \& R. Elphick (eds.), Christianity in south Africa: A political, social and cultural history, pp. 135-154, David Philip, Cape Town.

Lyon, D.H.S., 1998, In pursuit of a vision, St Andrew Press, Edinburgh.
Mackay, M., 1976, 'Change - But how?', Life and Work, August, pp. 10-11.

Sass, F.W., 1957, The influence of the Church of Scotland on the Dutch Reformed Church of South Africa, University of Edinburgh, Edinburgh.

Scottish A-A Movement (SAAM), 2018, viewed 20 November 2017, from fricanactivist. msu.edu/organization.php?name=Anti-A partheid+Movement $\% 3 A+S c o t t i s h+C o$ mmittee

Torrence, T.F., 1977, 'The moderator in South Africa', Life and Work, January, pp. 14-15.

Unknown Author, 1977, 'News from all q'arters', Life and Work, January, p. 34.

Unknown Author. 1981, 'Disagreement on South Africa', Life and Work, July, p. 26.

Unknown Author, 1983, 'Prayers for South Africa', Life and Work, August, p. 19.

Van der Water, D., 1991, 'Protest and celebration', in D. van der Water \& M. Worsnip (eds.), We shall overcome: A spirituality of liberation, pp. 90-111, Cluster, Pietermaritzburg.

Watson, D.S., 1982, 'The Gospel compels us to keep contact', Life and Work, July, pp. 26-27. 